\title{
TU/e EmonOWEN

\section{Students' learning patterns and learning spaces in higher education: an empirical investigation in China}

\section{Citation for published version (APA):}

Yu, J., Vermunt, J. D., \& Burke, C. (2021). Students' learning patterns and learning spaces in higher education: an empirical investigation in China. Higher Education Research \& Development, 40(4), 868-883. https://doi.org/10.1080/07294360.2020.1775557

\section{Document license:}

TAVERNE

DOI:

10.1080/07294360.2020.1775557

Document status and date:

Published: 01/05/2021

\section{Document Version:}

Publisher's PDF, also known as Version of Record (includes final page, issue and volume numbers)

\section{Please check the document version of this publication:}

- A submitted manuscript is the version of the article upon submission and before peer-review. There can be important differences between the submitted version and the official published version of record. People interested in the research are advised to contact the author for the final version of the publication, or visit the $\mathrm{DOI}$ to the publisher's website.

- The final author version and the galley proof are versions of the publication after peer review.

- The final published version features the final layout of the paper including the volume, issue and page numbers.

Link to publication

\section{General rights}

Copyright and moral rights for the publications made accessible in the public portal are retained by the authors and/or other copyright owners and it is a condition of accessing publications that users recognise and abide by the legal requirements associated with these rights.

- Users may download and print one copy of any publication from the public portal for the purpose of private study or research.

- You may not further distribute the material or use it for any profit-making activity or commercial gain

- You may freely distribute the URL identifying the publication in the public portal.

If the publication is distributed under the terms of Article 25fa of the Dutch Copyright Act, indicated by the "Taverne" license above, please follow below link for the End User Agreement:

www.tue.nl/taverne

Take down policy

If you believe that this document breaches copyright please contact us at:

openaccess@tue.nl

providing details and we will investigate your claim. 


\section{Students' learning patterns and learning spaces in higher education: an empirical investigation in China}

\section{Ji Yu, Jan D. Vermunt \& Catherine Burke}

To cite this article: Ji Yu, Jan D. Vermunt \& Catherine Burke (2021) Students' learning patterns and learning spaces in higher education: an empirical investigation in China, Higher Education Research \& Development, 40:4, 868-883, DOI: 10.1080/07294360.2020.1775557

To link to this article: https://doi.org/10.1080/07294360.2020.1775557

\section{冊 Published online: 11 Jun 2020.}

Submit your article to this journal $\widetilde{ }$

Lll Article views: 232

Q View related articles ¿

View Crossmark data \lceil

Citing articles: 1 View citing articles ¿ð 


\title{
Students' learning patterns and learning spaces in higher education: an empirical investigation in China
}

\author{
Ji Yu (1) ${ }^{a}$, Jan D. Vermunt $\mathbb{(}^{\mathrm{b}}$ and Catherine Burke ${ }^{\mathrm{c}}$

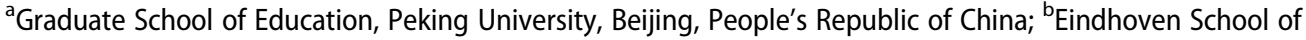 \\ Education, Eindhoven University of Technology, Eindhoven, The Netherlands; ' ${ }^{\mathrm{C}}$ aculty of Education, \\ University of Cambridge, Cambridge, United Kingdom
}

\begin{abstract}
Learning spaces in higher education are changing in crucial and myriad ways. It is important to know how learning spaces are associated with learning in order to provide students with the most appropriate spaces to learn. This study investigates the relationship between students' learning patterns and learning spaces in higher education through empirical work. It was divided into two phases - firstly, it selected two contrasting learning spaces in a Chinese university and used an adapted Inventory of Learning Styles (ILS) to compare how students went about their learning differently within the spaces. In the second stage, students were recruited to participate in focus group interviews, in which they were asked about their learning experiences of, and attitudes towards, the spaces. Quantitative and qualitative data were combined and analysed in order to identify patterns of covariation that related to features of students' learning patterns and preferences for learning spaces. The findings revealed that students with features of a typical application-directed learning pattern preferred flexible, innovative learning spaces; students who showed characteristics of a reproductive learning pattern considered traditional, didactic learning spaces as desirable or necessary; and students who adopted more strategies of a meaning-directed learning pattern placed less emphasis on the importance of space as they tended to choose different types of learning space according to their own learning needs. Implications for further research and practice of learning spaces in higher education, as well as the generalisability of the findings, are discussed.
\end{abstract}

\section{ARTICLE HISTORY}

Received 24 April 2019

Accepted 5 May 2020

\section{KEYWORDS}

Focus group interviews; higher education; Inventory of Learning Styles; learning patterns; learning space

\section{Introduction}

\section{Learning space in higher education}

The landscape of learning space design in higher education is undergoing a transformation. During the past two decades, new types of learning spaces have been established in many countries, often named 'effective learning spaces', 'inspirational or innovative learning spaces', 'new generation learning spaces/environments' (CABE, 2005; Fisher, 
2005; Harrison \& Hutton, 2014; JISC, 2006; Oblinger, 2006). Common features of these new learning spaces include motivating learners, supporting collaborative learning, providing a personalised and inclusive environment, and being flexible for different activities. Technology also plays a vital part in achieving these aims (Fisher \& Newton, 2014; Jamieson et al., 2000).

Contemporary discussions about learning spaces in higher education fall into three main areas (Ellis \& Goodyear, 2016): (1) pedagogy and curricula and their association with space; (2) learning space design; and (3) the development of ICTs and software tools that create virtual spaces. However, among the many methods employed to foster student learning, the use of space is perhaps the least understood and the most neglected (Strange \& Banning, 2001). Until now, the existence of evidence on the link between spatial design and pedagogical effectiveness in higher education is still sparse. Some exceptions can be found in the studies of Brooks (2011) and Walker, Christopher, Brooks, and Baepler (2011), who conducted a series of quasi-experimental studies to investigate the impact of learning space upon student learning behaviour and learning outcomes - the results showed that students taking the course in a technologically enhanced environment outperformed their peers who were taking the same course in a traditional classroom setting. Another example is a qualitative investigation of Matthews, Andrews, and Adams (2011), who found that informal social learning spaces could foster social interaction and a sense of belonging and community amongst students in broad disciplinebased programmes. Despite these increasing efforts, the literature remains segmented. It has been argued that the lack of conceptual coherence and the dearth of empirical evidence are placing a brake on the development and usefulness of learning space research and future construction investment, and there is a great need for rigorous knowledge of the links between space and student in higher education (Cleveland \& Fisher, 2014; Edwards, 2000; Tempe, 2007, 2008). To help remedy this situation, this study draws on theories and concepts concerning learning patterns, rooted in student learning research, in order to provide an insightful way to understand the underlying relationship between learning space and student learning in higher education, and hopefully provides a window into what that dynamic interplay may encompass.

\section{The learning pattern perspective on student learning}

Student learning has been an ongoing subject of study in higher education. Considerable effort has been expended on understanding and theorising student learning. Examples of different perspectives include approaches to learning (Biggs, 1993; Marton \& Säljö, 1976; Quinn \& Stein, 2013), conceptions of learning (Entwistle \& Peterson, 2004; Van Rossum \& Hamer, 2010), learning styles (Kolb, 1981), metacognition (Flavell, 1987), learning orientations (Beaty, Gibbs, \& Morgan, 1997), and situated learning (Aydede \& Robbins, 2009; Brown, Collins, \& Duguid, 1989). Some well-claimed conceptual frameworks include Entwistle and Peterson's (2004) framework that covers a variety of influences on high-quality learning, or the Teaching for Understanding framework developed by Project Zero at Harvard (Wiske, 1998). This study makes use of the learning pattern model as described below because it not only offers a fruitful insight into the multiple dimensions of student learning, but is also a useful tool to understand differences in individuals' learning and their differing demands of spaces. In addition, its 
instrument, the Inventory of Learning Styles (ILS), has been used in nearly 30 countries, including in the site of this study - mainland China, which gives the reliability of the investigation.

The learning pattern framework includes four central learning components that have been widely studied in student learning research (Vermunt \& Donche, 2017; Vermunt \& Vermetten, 2004): cognitive processing strategies, regulation strategies, conceptions of learning, and learning orientations. Its instrument measures the four learning components in 16 scales:

Component 1. Processing strategies - refer to the thinking activities that students use to process learning content. The three scales are Deep Processing, Surface Processing, and Concrete Processing.

Component 2. Regulation strategies - refer to students' activities for regulating and controlling the processing strategies. The three scales are Self-regulation, External Regulation, and Lack of Regulation.

Component 3. Learning orientations - refer to students' goals, motives, and concerns with regard to their studies. The five scales are Personally Interested, Certificate-oriented, Selftest-oriented, Vocation-oriented, and Ambivalent.

Component 4. Conceptions of learning - refer to students' views and beliefs about learning and related phenomena. The five scales are Construction of Knowledge, Intake of Knowledge, Use of Knowledge, Stimulating Education, and Cooperative Learning.

More details of the instrument can be found in Vermunt $(1998,2020)$.

A learning pattern is a coordinating concept of learners' cognitive and regulative strategies, their beliefs about learning and their learning orientation. A student's learning pattern is malleable, but it does not change day to day, it is a characteristic of a learner in a certain period of time (Vermunt \& Donche, 2017). Using factor analysis, four recurring learning patterns have been identified in a series of studies: undirected, reproductiondirected, meaning-directed and application-directed learning patterns (see e.g., LindblomYlänne, 2003; Lonka, Olkinuora, \& Makinen, 2004; Meyer, 2000; Vermunt, 1998). Their constituent learning components are presented in Table 1. Meaning-directed and application-directed learning patterns are usually related to good learning outcomes and are considered to be more desirable; the undirected learning pattern is undesirable, and there has been a debate regarding the necessity of the reproduction-directed learning pattern.

Table 1. Four learning patterns and their constituent learning components.

\begin{tabular}{|c|c|c|c|c|}
\hline \multirow[b]{2}{*}{$\begin{array}{l}\text { Learning } \\
\text { components }\end{array}$} & \multicolumn{4}{|c|}{ Learning patterns } \\
\hline & Undirected & $\begin{array}{l}\text { Reproduction- } \\
\text { directed }\end{array}$ & Meaning-directed & Application-directed \\
\hline $\begin{array}{l}\text { Cognitive processing } \\
\text { strategies }\end{array}$ & Hardly any processing & Stepwise processing & Deep processing & Concrete processing \\
\hline $\begin{array}{l}\text { Regulation of } \\
\text { learning }\end{array}$ & Lack of regulation & External regulation & Self-regulation & $\begin{array}{l}\text { Both external and } \\
\text { self-regulated }\end{array}$ \\
\hline $\begin{array}{l}\text { Conceptions of } \\
\text { learning }\end{array}$ & $\begin{array}{l}\text { Cooperation and being } \\
\text { stimulated by others }\end{array}$ & Intake of knowledge & $\begin{array}{l}\text { Construction of } \\
\text { knowledge }\end{array}$ & Use of knowledge \\
\hline $\begin{array}{l}\text { Learning } \\
\text { orientations }\end{array}$ & Ambivalent & $\begin{array}{l}\text { Certificate or self-test } \\
\text { oriented }\end{array}$ & $\begin{array}{l}\text { Personally } \\
\text { interested }\end{array}$ & Vocation oriented \\
\hline
\end{tabular}

Source: Vermunt (1996). 


\section{The present study}

This study selected two contrasting learning spaces in a middle-sized university in mainland China for investigation - a conventional, didactic learning space (Space A) and a flexible, innovative learning space (Space B). Both were generic learning spaces designed for all types of student in the university. Prior to this study, interviews were carried out with educators and designers of the two spaces in order to discover the embedded pedagogical visions and anticipations of student learning, which helped to set the hypotheses of the study. These interviews found that Space A retained a strong focus on the content being taught. Students were expected to acquire knowledge mainly through using processing strategies like memorising and reproducing, and regulated by external sources such as instructions or assignments of teachers. The main 'space spirit' was discipline and collectivism, reflected in its traditional architectural academic style, plain colour and didactic classroom setting (Figure 1).

By contrast, Space B was intended to provide a motivational and emotional atmosphere for students' creative thinking and interdisciplinary study. Students were expected to be more self-regulated in their learning processes and in the usage of space. Its 'space spirit' is relaxedness and openness, realised through a rich colour scheme, comfortable furnishing, spatial division and flexibility, and the creation of a sense of ownership and autonomy (Figure 2).

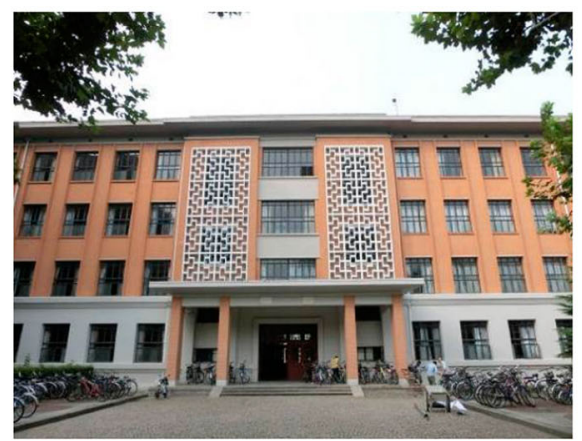

(a) Building appearance

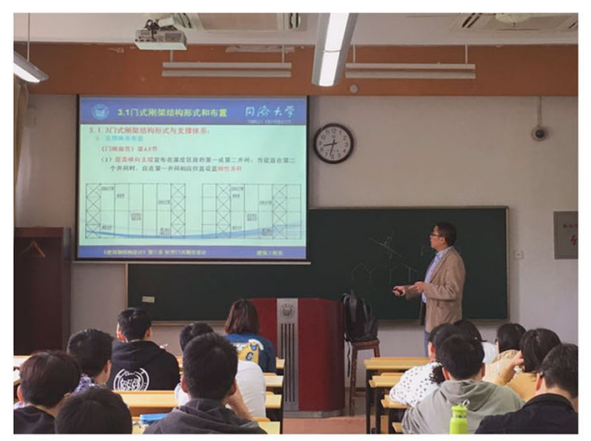

(c) Teaching activity taking place in the space

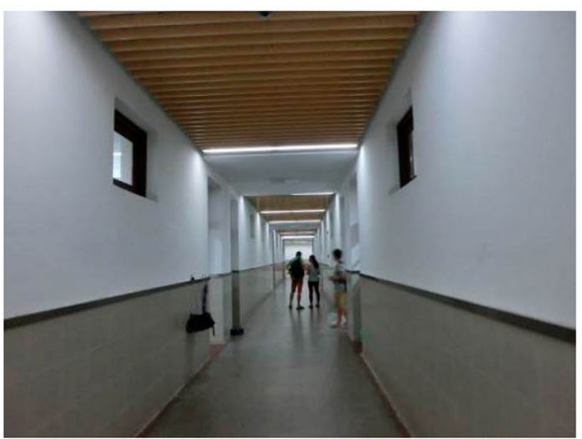

(b) The straight inner corridor

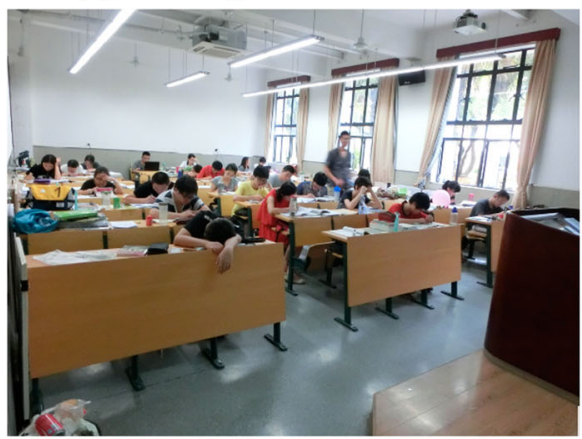

(d) Students' self-study activity in the space

Figure 1. Space A (The source of Photo C: the involved teacher and students). 


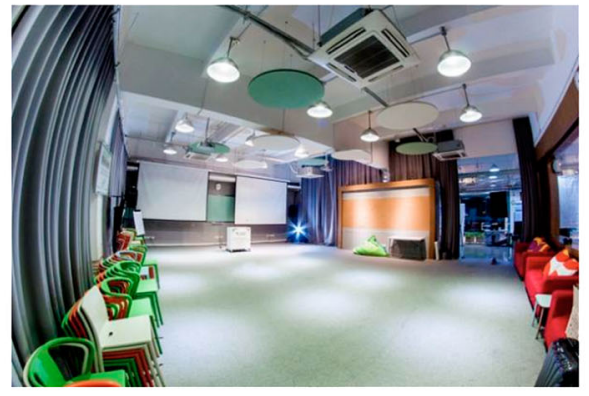

(a) Multi-purpose lecture room

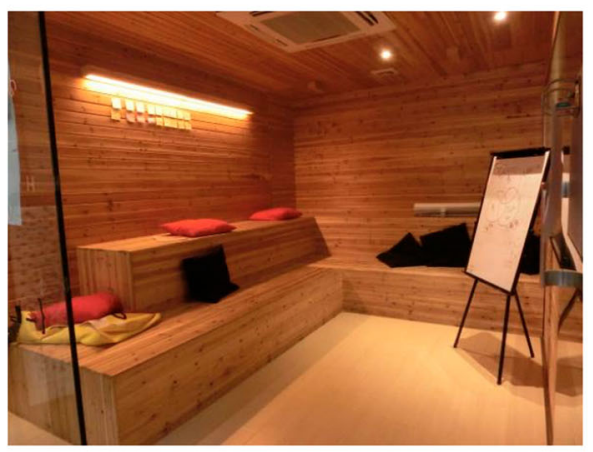

(c) Group work space

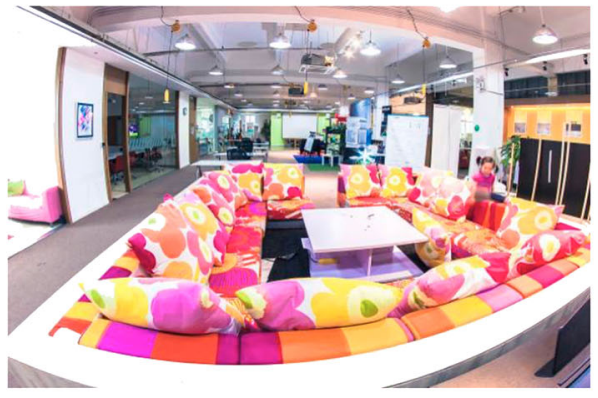

(b) Public space

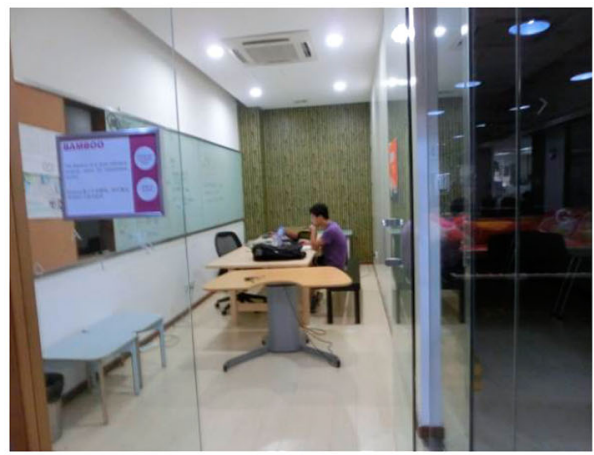

(d) Private study space

Figure 2. Space B (The source of Photos A and B: Sino-Finnish Centre).

Based on these preliminary works, the study set up two research questions, divided into two sub-studies:

(1) How do students in the two contrasting learning spaces differ from each other in terms of the cognitive and regulative learning strategies they use, the conceptions of learning they adhere to, and the learning orientations they have?

(2) How do students with features of different learning patterns prefer the contrasting learning spaces? How do they differ in the specific needs for learning space?

\section{Method}

\section{The instruments}

For the first research question, the 100-item version of ILS in Simplified Chinese characters (Vermunt, 1994, translated by Sun, 2012) was adapted and used. Adaptions were made in two aspects: (1) an introduction about the research project and its focus on the relationship between space and learning was given. Students were asked to complete the survey according to their learning experiences within the particular space where the questionnaires were handed out. (2) In Part A 'Study Activities', 'here' was added at the end of the original response scales. Below is an example of the items: 


\begin{tabular}{llccc}
\hline 1 & 2 & 3 & 4 & 5 \\
$\begin{array}{l}\text { I do this seldom or never } \\
\text { here }\end{array}$ & $\begin{array}{l}\text { I do this sometimes } \\
\text { here }\end{array}$ & $\begin{array}{l}\text { I do this regularly } \\
\text { here }\end{array}$ & $\begin{array}{c}\text { I do this often } \\
\text { here }\end{array}$ & $\begin{array}{c}\text { I do this almost always } \\
\text { here }\end{array}$ \\
\hline
\end{tabular}

2. I repeat the main parts of the subject matter until I know them by heart. $1 \quad 2 \quad \begin{array}{lllll} & 3 & 4 & 5\end{array}$

In addition, to gather the information regarding students' demographic backgrounds, also for the purpose of recruiting participants for the follow-up research, students were asked to complete questions relating to their gender, age, academic discipline, year of study and contact information. To avoid confusion about the classification of 'discipline', they were asked to write down their university departments.

For the second research question, FGIs were carried out using a conversational style, with students being encouraged to reflect on their own experiences in as much depth as they were able to. Compared with individual interviews, FGIs have the advantage of stimulating discussion and generating rich data quickly. The interaction between participants also serves as a memory trigger for participants to reflect on their opinions and experience (Kitzinger, 1994). The interview schedule contained a series of open-ended questions about the link about space and learning: (1) how students understand learning space'; (2) how students learn within the particular space; (3) how space affects their learning; and (4) students' requirements of, and preferences for learning space, which were often interwoven in students' responses. The researcher stayed open to new ideas put forward by participants, and probes were used during the interviews. To reduce the influence of dominant voices and obtain comparable data from all respondents, also to strengthen the power of qualitative data, in the middle of the FGIs students were given a note to independently write down the influential elements of a space on their learning.

\section{Participants}

In order to cover a sample of students from diverse disciplines and in different years of university education, the ILS questionnaires were handed out on public elective courses within the two spaces. All students in the university were subject to the same credit requirements of public elective courses. Students could express their interest in particular courses via the registration system, but the final distribution was based on an online random assignment because class size of each course was fixed and resources needed to be balanced. A total of 320 students took part in the survey, with 171 participants in Space A and 149 students in Space B. The valid sample was 318 as two students (one in each space) completed only one-third of the questionnaire so they were not included in the analyses. Participants came from 20 departments of the university, and their subject information was re-coded according to the standard classification of disciplines used in the research site country: natural sciences, engineering and technology, arts and social sciences, and medicine. The distribution of participants' demographic information (age, gender, subject) is shown in Table 2.

Participants of FGIs were recruited from 274 students who had provided their contact information on the questionnaires. Of these, 45 (21 in Space A and 24 in Space B) expressed their willingness to participate and stated their time availability. A pilot with 
Table 2. Means and standard deviations (M and SD) of the age, frequencies (N) and percentage of the values on gender and subject of participants.

\begin{tabular}{|c|c|c|c|c|c|c|}
\hline \multirow[b]{2}{*}{ Personal variables } & \multicolumn{2}{|c|}{$M$ and $S D$} & \multicolumn{2}{|c|}{ N } & \multicolumn{2}{|c|}{$\%$} \\
\hline & Space A & Space B & Space A & Space B & Space A & Space B B \\
\hline \multicolumn{7}{|l|}{ Age } \\
\hline Mean & 18.7 & 20.3 & & & & \\
\hline Standard deviation & 1.20 & 3.00 & & & & \\
\hline No value & & & 3 & 2 & 1.8 & 1.4 \\
\hline \multicolumn{7}{|l|}{ Gender } \\
\hline 1: Male & & & 98 & 87 & 57.6 & 58.8 \\
\hline 2: Female & & & 72 & 60 & 42.4 & 40.5 \\
\hline No value & & & 0 & 1 & 0 & 0.7 \\
\hline \multicolumn{7}{|l|}{ Subjects } \\
\hline Natural sciences & & & 30 & 11 & 17.6 & 7.4 \\
\hline Engineering \& Technology & & & 78 & 53 & 45.9 & 35.8 \\
\hline Arts and social sciences & & & 41 & 54 & 24.1 & 36.5 \\
\hline Medicine & & & 5 & 4 & 2.9 & 2.7 \\
\hline No value & & & 16 & 26 & 9.4 & 17.6 \\
\hline Total number & & & 170 & 148 & 100.0 & 100.0 \\
\hline
\end{tabular}

4 students lasted 80 min, therefore the group size of the main FGIs was kept at four to six participants so that a single interview lasted no longer than $120 \mathrm{~min}$. Six FGIs with 28 participants were finally conducted, with three taking place within each space. The sample consisted of students of different gender, year of study and subject. With informed consent from all participates, the FGIs were recorded for the purpose of data analysis.

\section{Data analysis}

\section{Research question 1}

Data were analysed using the SPSS statistical package. The data were firstly checked to see whether they were parametric to decide whether to use parametric or non-parametric comparative analysis. The normality of the 16 ILS scales was examined with ShapiroWilk (S-K) as it is in general more accurate than Kolmogorov-Smirnov (K-S) (Field, 2009 , p. 527, p. 546). The output showed that 11 of the subscales of ILS in Space A and 8 in Space B showed non-normal distributions $(p<.05)$. Box's test $(.01)$ also showed that the homogeneity assumption between the groups was violated. Therefore, a non-parametric Mann-Whitney U test was used.

\section{Research question 2}

To answer the second research question, the quantitative survey and qualitative data were combined. The analysis was individually oriented - an individual's ILS data and interview data were considered as an entity of one student. A1-A14 was used as identifications for the 14 participants in Space A, and B1-B14 for the 14 participants in Space B. The analysis procedure included two steps: firstly, students were allocated into different subgroups according to their ILS data. This was decided by examining on which scales the student reported higher than the mean scores of all participants. For example, if a student scored higher than average on the scales Concrete processing, Use of knowledge and Vocation orientation, he/she was allocated to the application-directed learning pattern. Secondly, we drew contrasts between individuals within the same subgroup and across different subgroups. In other words, we looked for whether there were certain parallels 
between the way students went about their learning and their attitudes towards learning spaces. The main tactics used were noting recurring patterns, describing and making contrasts (Miles \& Huberman, 1994).

\section{Results}

\section{Research question 1}

In Table 3 the differences on the ILS scales between students from the two spaces are presented.

As we can see, with regard to processing strategies, students in Space B reported using more concrete processing strategies than those in Space A. For conceptions oflearning, Space B students saw learning more as use of knowledge than those in Space A. They also scored higher on the scale of cooperative learning. For the learning orientations component, there was a significant difference on the vocation-oriented scale - Space B students scored significantly higher than Space A. Regarding regulation strategies, Space A students scored higher on the

Table 3. Mann-Whitney $U$ test for differences on the ILS scales based on spaces ( $N=170$ in Space $A ; N$ $=148$ in Space B).

\begin{tabular}{|c|c|c|c|c|c|}
\hline \multirow{2}{*}{$\begin{array}{l}\text { Inventory scales } \\
\text { Processing strategies }\end{array}$} & \multicolumn{2}{|c|}{ Mean rank } & \multirow[t]{2}{*}{$U$} & \multirow[t]{2}{*}{$Z$} & \multirow[t]{2}{*}{ Sig (2-tailed) } \\
\hline & & & & & \\
\hline \multirow{2}{*}{ Deep processing } & Space A & 153.91 & 11,629 & -1.16 & .24 \\
\hline & Space B & 165.93 & & & \\
\hline \multirow[t]{2}{*}{ Stepwise processing } & Space A & 162.18 & 12,125 & -0.56 & .58 \\
\hline & Space B & 156.42 & & & \\
\hline \multirow[t]{2}{*}{ Concrete processing } & Space A & 139.93 & 9252 & -4.08 & $.00^{*}$ \\
\hline & Space B & 181.98 & & & \\
\hline \multicolumn{6}{|l|}{ Regulation strategies } \\
\hline \multirow[t]{2}{*}{ Self-regulation } & Space A & 154.36 & 11,506 & -1.07 & .28 \\
\hline & Space B & 165.41 & & & \\
\hline \multirow[t]{2}{*}{ External regulation } & Space A & 166.76 & 11,346 & -1.51 & .13 \\
\hline & Space B & 151.16 & & & \\
\hline \multirow[t]{2}{*}{ Lack of regulation } & Space A & 156.72 & 12,108 & -0.58 & .56 \\
\hline & Space B & 162.69 & & & \\
\hline \multicolumn{6}{|l|}{ Conceptions of learning } \\
\hline \multirow[t]{2}{*}{ Construction of knowledge } & Space A & 161.51 & 12,238 & -0.42 & .67 \\
\hline & Space B & 157.19 & & & \\
\hline \multirow[t]{2}{*}{ Intake of knowledge } & Space A & 153.00 & 11,475 & -1.36 & .18 \\
\hline & Space B & 166.97 & & & \\
\hline \multirow[t]{2}{*}{ Use of knowledge } & Space A & 143.39 & 9840 & -3.37 & $.00^{*}$ \\
\hline & Space B & 178.01 & & & \\
\hline \multirow[t]{2}{*}{ Stimulating education } & Space A & 157.19 & 12,186 & -0.49 & .63 \\
\hline & Space B & 162.16 & & & \\
\hline \multirow{2}{*}{ Cooperative learning } & Space A & 139.14 & 9118 & -4.25 & $.00^{*}$ \\
\hline & Space B & 182.89 & & & \\
\hline \multicolumn{6}{|l|}{ Learning orientations } \\
\hline \multirow[t]{2}{*}{ Personally interested } & Space A & 151.88 & 11,284 & -1.59 & .11 \\
\hline & Space B & 168.26 & & & \\
\hline \multirow[t]{2}{*}{ Certificate oriented } & Space A & 153.77 & 11,606 & -1.20 & .23 \\
\hline & Space B & 166.08 & & & \\
\hline \multirow{2}{*}{ Self-test oriented } & Space A & 166.07 & 11,463 & -1.37 & .17 \\
\hline & Space B & 151.96 & & & \\
\hline \multirow[t]{2}{*}{ Vocation oriented } & Space A & 149.16 & 10,822 & -2.16 & $.03^{*}$ \\
\hline & Space B & 171.38 & & & \\
\hline \multirow[t]{2}{*}{ Ambivalent } & Space A & 159.74 & 12,538 & -0.05 & .96 \\
\hline & Space B & 159.22 & & & \\
\hline
\end{tabular}

* Statistically significant, $p<.05$. 
external regulation scale, while Space B students reported higher on both scales of self-regulation and lack of regulation, but these differences were not statistically significant.

To gain an integrated idea of the group differences, we put these results back into the four recurring learning patterns revealed in previous research, as presented in Table 1. Three of the four scales on which students in the two spaces differed significantly (Concrete processing strategies, Use of knowledge and Vocation-oriented scales) fall into the applicationdirected learning pattern. Although the scale 'cooperative learning' is initially grouped under the undirected learning pattern, indicating that students attach great value to being stimulated by others and is considered as a passive conception of learning, this result may be translated differently in this study. In Space B, it was believed that cooperative learning between students plays an indispensable role in project-based learning; therefore, it is more appropriate to group the cooperative learning scale under the application-directed and meaning-directed learning patterns instead of the undirected learning pattern here.

\section{Research question 2}

Three distinguishable groups were identified according to the features of individuals' ILS data and their preferences for learning space. Table 4 presents the overall pattern of the findings, followed by the explanation and examples manifested in each group. Selection of the excerpts were subject to the clarity of individuals' own reasoning. Although all participants expressed their attitudes towards the learning spaces explicitly as shown in Table 4, not everyone provided detailed explanations (for instance, some students simply replied 'I agree', 'Yes, that's true'). Below we present some clear explanations from the data. To optimally capture the underlying reasons and provide a comprehensive picture of each group, we tried to cover the responses of students from different demographics (gender, discipline, year of study) within the group. Therefore, although the quotations are individual, they are representative in terms of individuals' responses within the group and the multiple potential reasons.

First of all, the three groups had some common requirements of learning spaces in terms of: (1) accessibility of space, which students referred to the appropriate capacity, location and opening hours of a learning space; (2) Low noise level, by which students meant that the disturbance made by sound is well controlled; and (3) Air quality, in which students discussed the ventilation and temperature within a learning space.

Table 4. Outline findings indicating the preferences for, and requirements of, learning spaces of three groups of students, differing in their characteristic learning patterns.

\begin{tabular}{|c|c|c|c|}
\hline $\begin{array}{l}\text { Distinguishable } \\
\text { students' learning } \\
\text { patterns }\end{array}$ & $\begin{array}{c}\text { Group 1: reproduction-directed } \\
\text { learning }(N=9)\end{array}$ & $\begin{array}{l}\text { Group 2: application-directed } \\
\text { learning }(N=10)\end{array}$ & $\begin{array}{c}\text { Group 3: meaning- } \\
\text { directed learning }(N= \\
4)\end{array}$ \\
\hline $\begin{array}{l}\text { Preferences for } \\
\text { learning space }\end{array}$ & Space A & Space B & $\begin{array}{l}\text { Choose different } \\
\text { learning space } \\
\text { according to as the } \\
\text { learning task }\end{array}$ \\
\hline $\begin{array}{l}\text { Shared requirements } \\
\text { of learning space }\end{array}$ & & $\begin{array}{c}\text { Accessibility of space } \\
\text { Level of noise } \\
\text { Air quality }\end{array}$ & \\
\hline $\begin{array}{l}\text { Differentiated } \\
\text { requirements of } \\
\text { learning space }\end{array}$ & Learning atmosphere & $\begin{array}{l}\text { Inspirational nature of space, } \\
\text { Collaborative learning space, } \\
\text { Flexibility of space, Desks and } \\
\text { chairs, Private space }\end{array}$ & $\mathrm{N} / \mathrm{A}$ \\
\hline
\end{tabular}


The groups had contrasting preferences for a learning space. Group 1 students, who showed more features of a reproduction-directed learning pattern, perceived a traditional space like Space A to be 'preferable, good, or necessary'; participants who were interviewed within Space B also considered that although the creative space was good for classes, they would not go there for individual study because the place was too relaxed and comfortable to evoke a sense of learning. In other words, it did not provide a good 'learning atmosphere'. Below are some examples of students' explanations in this group.

A2 (male, second year undergraduate, civil engineering): The space reminds me of the days in senior school; everyone is learning, so you can learn easily - there is kind of psychological hint. I think too comfortable spaces distract me from learning, they make me fall asleep easily.

A3 (female, third year undergraduate, life sciences): I believe this traditional learning space has its necessity, because if group work is used here ... is hard for teachers to manage, and for students to concentrate.

B2 (male, first year undergraduate, automotive engineering): One of our courses is mechanical drawing, you need to draw tiny things on A2 paper. I normally do that in the dormitory because I like to draw together with my roommates ... the work is quite boring, you can chat with others when you draw. And if there is any problem, you can communicate with others.

B11 (male, first year postgraduate, automotive engineering): There are too many things here (Space B), every time you look up, you may see something to distract your concentration. It is too comfortable, which makes me easily feel slack. Spaces like the library and Space A can better stimulate my motivation to learn.

Students in Group 2, with more features of the application-directed learning pattern, perceived Space A as a 'less suitable place for learning' or 'last choice for learning' and considered Space B to be more desirable. Apart from the common requirements of space as described above, these students paid more attention to: (1) inspirational nature of space, which means the spatial design and furnishing can help to inspire students' imagination and creative thinking. (2) collaborative space; (3) flexibility of space; (4) sense of ownership and autonomy; (5) comfortable desks and chairs; and (6) space privacy. Examples are presented in Table 5.

Students in Group 3, who characteristically adopted the meaning-oriented learning pattern, considered space to be less influential for their learning. They tended to choose different learning spaces according to the learning task. Examples are shown below:

A6 (female, first year undergraduate, economic management): I can learn in any place if the deadline is coming. I think learning is not dependent on someone else affecting you or where you are, but initiated by yourself.

A10 (male, third year undergraduate, geological engineering): I agree with her. For me, learning space does not have much influence; because I tend to do self-regulated learning, the external environment, except noise and air quality, cannot really affect me.

B14 (male, first year postgraduate, design): If I have several learning tasks to do, I'll choose to do the most arduous work, such as reciting, reading or doing research, in a conventional learning space because it helps to calm down and force myself to learn. For creative activities, I'd like to go to a more innovative learning space.

Apart from the three groups, there was a minority of students among the 28 participants who could not be assigned to any of the three groups above. In Space A, there 
Table 5. The requirements of a learning space in Group 2 students, who preferred a flexible, innovative learning space like Space B.

\begin{tabular}{|c|c|}
\hline $\begin{array}{l}\text { Requirements of learning } \\
\text { space }\end{array}$ & Examples from the data (summarised) \\
\hline Inspirational nature of space & $\begin{array}{l}\text { Compared to traditional learning spaces, I think this space (Space B) is more fashionable, } \\
\text { more diversified. Its furniture and colour are more rich and vivid, which is refreshing. I think, } \\
\text { when you engage it with curiosity, your learning results will get better. }\end{array}$ \\
\hline Collaborative learning space & $\begin{array}{l}\text { We have a course of language improvement taking place in traditional spaces (Space A), it is } \\
\text { kind of discussion, but we feel very stiff there... people raise their hands for discussion, even } \\
\text { though the teacher asks them not to do so. }\end{array}$ \\
\hline Flexibility of space & $\begin{array}{l}\text { Flexibility is important, because it makes me feel I can take control of my learning. If I read too } \\
\text { much and feel tired, I can stretch myself to relax or discuss with others here, which is } \\
\text { inconvenient in the library or the Space A because you will disturb others. So I don't often go } \\
\text { to those spaces, because I prefer learning flexibly. }\end{array}$ \\
\hline $\begin{array}{l}\text { Sense of ownership and } \\
\text { autonomy }\end{array}$ & $\begin{array}{l}\text { After staying here (Space B) for about one or two months, the space gives me a sense of } \\
\text { territory. I came here to write my graduation thesis, with another three classmates. We drew } \\
\text { countdown and graffiti on the blackboard every day, which gave us fun during learning. We } \\
\text { cannot get this kind of pleasure in the library or Space A. }\end{array}$ \\
\hline Desks and chairs & $\begin{array}{l}\text { I feel here (Space A) is only a place for listening to class, it is almost my last choice for self- } \\
\text { studying. Sometimes when I study, I need different colours of pens, material. I need to place } \\
\text { them on the table, and the tables here are just too small. }\end{array}$ \\
\hline Space privacy & $\begin{array}{l}\text { One thing that I do not like about this learning space (Space A) is there are no divisions. } \\
\text { People walk here and there, you just feel that someone can suddenly stand behind you, } \\
\text { although he is probably not looking at you, but it makes me feel very unsafe. }\end{array}$ \\
\hline
\end{tabular}

were two students - A4 and A7, whose ILS results could not be grouped according to any typical learning pattern, as they showed a dissonant combination of different learning patterns. A4, a female first-year student in natural sciences, reported high scores for deep and concrete processing strategies, but with a lack of regulation and an ambivalent learning conception. A7, who was a female first-year civil engineering student, showed average levels on all scales of the four learning components. In Space B, there was a surprising contrast - B5 and B8, who were two students who most appreciated the space's effectiveness of fostering creative thinking during the FGIs, had ILS results that showed distinct pictures. B5 showed a combination of meaning-directed and application-directed learning patterns, which is normally considered to be 'high quality learning' in higher education, while B8 reported clear features of an undirected learning pattern, which is normally considered as 'less desirable learning' in higher education.

\section{Conclusions and discussion}

The present study has drawn on learning pattern theories in order to explore the relationship between space and learning in higher education. The findings suggest that a flexible, innovative space like Space B is positively associated with students' adoption of an application-directed learning pattern and can be considered as a contributor in helping students to be better prepared for future careers. This is manifested not only in students' ILS results, but also in students' specific sense-making with regard to the impact of different learning spaces. However, it needs to be recognised that such a claim does not indicate a causal link as other interweaving factors may exist in such relationships, such as students' selection of the university, the adopted pedagogies, and the influence of other space users (Yu, 2019).

Advocates of new learning spaces usually anticipate an overall greater satisfaction with these learning spaces, but the present study showed a more subtle picture. No statistically 
significant differences were revealed on those scales of meaning-directed learning pattern and reproductive learning pattern, indicating that: (1) we know less about how to foster a rigorous appreciation of the internal structure of a subject and the development of integrative understanding and deep thinking in students through the use of learning space; and (2) the reproductive learning pattern (or surface approaches to learning) may be essential for students as rote learning of technical terms can be an essential prerequisite for developing conceptual understanding in some subject areas (Entwistle, 2009). The first question reminds the authors of an informative feedback from one participant, who expressed her concern that learning activities in Space B were occasionally kept discursively without pulling people's minds back at the right time. It was in line with the observation of Beckers, Van Der Voordt, and Dewulf (2016) that many higher education buildings particularly focus on facilitating collaborative and social activities but lack sufficient spaces for retreat. Park and Choi (2014) have argued that the combination of traditional classrooms and new learning spaces will facilitate development in education best. The second issue appears to be consistent with the observation in previous studies that interventions aiming to improve student learning in higher education should be concerned more with encouraging a deep approach rather than discouraging a reproductive or surface approach (Trigwell \& Prosser, 1991). It may be also possibly related to features of 'Chinese learners' - some studies have found that ethnically Chinese students tend to adopt a distinctive approach to studying that combines memorising with understanding (Kember, 1996; Richardson \& Sun, 2016; Watkins \& Biggs, 1996).

Analyses on the FGIs supplement the questionnaire findings and reveal a more finegrained pattern. In general, there are three different types of association between students' learning patterns and their preferences for learning spaces: (1) students categorised as adopting a typical application-directed learning pattern preferred a flexible learning space like Space B; (2) students who showed more characteristics of the reproductive learning pattern considered a learning space like Space A as desirable or necessary; (3) students who adopted more strategies of the meaning-directed learning pattern placed less emphasis on the importance of learning spaces as they tended to take more control of the use of different types of learning space. These results, to some extent, are in line with Wilson and Fowler's (2005) finding that students categorised as 'typically deep' in their approach to learning were consistent in their approaches to learning across conventional and action learning designs; and also consistent with the observation of Beckers et al. (2016) that students mainly use open areas to work in small groups and social activities.

The findings have some implications for learning space research and practice in higher education. One the one hand, providing new types of learning space is likely to increase students' awareness of the role of space in their learning, and have particularly vocational benefits for students. On the other hand, open, innovative spaces, like Space B, which people nowadays are keen to create, could possibly be a 'double-edged sword' for students - it might have helped a good learner to learn better, but also led those with a 'low quality of learning' to learn even less well. Therefore, a solid empirical base to verify the educative effectiveness of these new spaces as well as the balance between new learning spaces and traditional classrooms is required in the future. The present study also allows us to reflect on the value of mixed methods for spacerelated research. As Fisher and Newton (2014) suggest, both quantitative and qualitative 
methods should be used to study the usability and educative value of learning spaces. To the authors' best knowledge, this study is the first that incorporates a comprehensive measure of learning patterns with the qualitative FGI method. The data analyses that combined the variable-oriented perspective with an individual-oriented approach have helped to better and more completely answer the research questions. However, ILS and FGIs are both based on students' self-reported learning experiences, and future studies may combine more naturalistic or innovative tools such as observation, eye tracking or diary method.

Regarding the generalisability of the findings, it is always questionable to extrapolate the findings of a specific study; however, the tension between the two distinct learning spaces are currently common in many other places (Jamieson, Fisher, Gilding, Taylor, \& Trevitt, 2000) - to some extent, it represents the movement from a teacher-oriented instructional paradigm to a more collaborative, self-regulated, problem-based approach. From this point of view, the results are transferrable in different universities and cultural contexts. Although the study takes place in China, there is no clear evidence showing that Chinese students' choice to use a learning space is culturally determined. However, it is worthwhile to consider students' different locality and adaptability to new learning spaces in applying the results.

This study has some limitations. First, it adopts an overall comparative research design; in real learning situations, students learn in different places at university so that their interactions with spaces are not static. How to examine the complex joint effect of different learning spaces will be an important research issue. Second, due to practical constraints, this study was carried out in a cross-sectional way, and longitudinal research and experimental design will be needed in order to establish causal claims between space and learning. In addition, student personal characteristics like gender, age and discipline are not discussed elaborately in this article; they are reported in another forthcoming article by the authors.

In conclusion, this study has established a meaningful link between student learning patterns and learning spaces through empirical work, and contributed to the literature on both constructs. It is hoped that such effort will inspire a new way of understanding the interplay between space and learning in higher education, and shed some light on this research field that requires substantial research in the future.

\section{Acknowledgements}

The authors wish to thank the participants, the management staff of the two spaces for their cooperation with the study and permission for accessing to relevant materials and records.

\section{Disclosure statement}

No potential conflict of interest was reported by the author(s).

\section{ORCID}

Ji Yu (D) http://orcid.org/0000-0002-7102-2288

Jan D. Vermunt (D) http://orcid.org/0000-0001-9110-4769 


\section{References}

Aydede, M., \& Robbins, P. (Eds.). (2009). The Cambridge handbook of situated cognition. New York: Cambridge University Press.

Beaty, E., Gibbs, G., \& Morgan, A. (1997). Learning orientations and study contracts. In F. Marton, D. J. Hounsell \& N. J. Entwistle (Eds.), The experience of learning (2nd ed., pp. 72-88). Edinburgh: Scottish Academic Press.

Beckers, R., Van Der Voordt, T., \& Dewulf, G. (2016). Why do they study there? Diary research into students' learning space choices in higher education. Higher Education Research \& Development, 35(1), 142-157.

Biggs, J. (1993). From theory to practice: A cognitive systems approach. Higher Education Research \& Development, 12(1), 73-85.

Brooks, C. (2011). Space matters: The impact of formal learning environments on student learning. British Journal of Educational Technology, 42(5), 719-726.

Brown, J. S., Collins, A., \& Duguid, P. (1989). Situated cognition and the culture of learning. Educational Researcher, 18(1), 32-42.

Cleveland, B., \& Fisher, K. (2014). The evaluation of physical learning environments: A critical review of the literature. Learning Environments Research, 17, 1-28.

Commission for Architecture and the Built Environment (CABE). (2005). Design with distinction: The value of good building design in higher education. London: CABE.

Edwards, B. (2000). University architecture. London: Spon Press.

Ellis, R. A., \& Goodyear, P. (2016). Models of learning space: Integrating research on space, place, and learning in higher education. Review of Education, 4(2), 149-191.

Entwistle, N. (2009). Teaching for understanding at university: Deep approaches and distinctive ways of thinking. London: Palgrave Macmillan.

Entwistle, N., \& Peterson, E. (2004). Conceptions of learning and knowledge in higher education: Relationships with study behaviour and influences of learning environments. International Journal of Educational Research, 41(6), 407-428.

Field, A. (2009). Discovering statistics using SPSS (3rd ed.). London: Sage Publications.

Fisher, K. (2005). Linking pedagogy and space: Planning principles for Victorian schools based on the principles of teaching and learning. Retrieved February, 2015, http://webfronter.com/ camden/learning/mnu3/images/Linking_Pedagogy_and_Space_Australia.pdf

Fisher, K., \& Newton, C. (2014). Transforming the twenty-first-century campus to enhance the netgeneration student learning experience: Using evidence-based design to determine what works and why in virtual/physical teaching spaces. Higher Education Research \& Development, 33(5), 903-920.

Flavell, J. H. (1987). Speculations about the nature and development of metacognition. In F. E. Weinert \& R. H. Kluwe (Eds.), Metacognition, motivation and understanding (pp. 21-29). Hillsdale, NJ: Erlbaum.

Harrison, A., \& Hutton, L. (2014). Design for the changing educational landscape: Space, place and learning. Abingdon: Routledge.

Jamieson, P., Fisher, K., Gilding, T., Taylor, P. G., \& Trevitt, A. C. F. (2000). Place and space in the design of new learning environments. Higher Education Research \& Development, 19(2), 221236.

Joint Information Systems Committee (JISC). (2006). Designing spaces for effective learning: A guide to 21st century learning space design. Bristol, UK: JISC Development Group. Retrieved July, 2012, https://www.webarchive.org.uk/wayback/archive/20140616001949/http://www.jisc.ac.uk/media/ documents/publications/learningspaces.pdf

Kember, D. (1996). The intention to both memorise and understand: Another approach to learning? Higher Education, 31(3), 341-354.

Kitzinger, J. (1994). The methodology of focus groups: The importance of interaction between research participants. Sociology of Health and Illness, 16, 103-121.

Kolb, D. A. (1981). Learning styles and disciplinary differences. In A. W. Chickering (Ed.), The modern American College (pp. 232-255). San Francisco, LA: Jossey-Bass. 
Lindblom-Ylänne, S. (2003). Broadening an understanding of the phenomenon of dissonance. Studies in Higher Education, 28, 63-77.

Lonka, K., Olkinuora, E., \& Makinen, J. (2004). Aspects and prospects of measuring studying and learning in higher education. Educational Psychology Review, 16, 301-323.

Marton, F., \& Säljö, R. (1976). On qualitative differences in learning-II outcome as a function of the learner's conception of the task. British Journal of Educational Psychology, 46, 115-127.

Matthews, K. E., Andrews, V., \& Adams, P. (2011). Social learning spaces and student engagement. Higher Education Research \& Development, 30(2), 105-120.

Meyer, J. H. F. (2000). The modelling of 'dissonant' study orchestration in higher education. European Journal of Psychology of Education, 15, 5-18.

Miles, M. B., \& Huberman, A. M. (1994). Qualitative data analysis. California: Sage.

Oblinger, D. G. (2006). Learning spaces. EDUCAUSE. Retrieved April, 2010, https://www.educause. edu/research-and-publications/books/learning-spaces

Park, E. L., \& Choi, B. K. (2014). Transformation of classroom spaces: Traditional versus active learning classroom in colleges. Higher Education, 68(5), 749-771.

Quinn, F., \& Stein, S. (2013). Relationships between learning approaches and outcomes of students studying a first-year biology topic on-campus and by distance. Higher Education Research \& Development, 32(4), 617-631.

Richardson, J. T. E., \& Sun, H. (2016). Approaches to studying among international students from China. In D. Jindal-Snape \& B. Rienties (Eds.), Multi-dimensional transitions of international students to higher education (pp. 106-122). New York: Routledge.

Strange, C., \& Banning, J. (2001). Educating by design: Creating campus learning environments that work. San Francisco: Jossey-Bass.

Tempe, P. (2007). Learning spaces for the 21st century: A review of the literature. York: Higher Education Academy.

Temple, P. (2008). Learning spaces in higher education: An under-researched topic. London Review of Education, 6(3), 229-241.

Trigwell, K., \& Prosser, M. (1991). Improving the quality of student learning: The influence of learning context and student approaches to learning on learning outcomes. Higher Education, 22, 251-266.

Van Rossum, E. J., \& Hamer, R. N. (2010). The meaning of learning and knowing. Rotterdam: Sense Publishers.

Vermunt, J. D. (1994). Inventory of learning styles in higher education. Tilburg, The Netherlands: Tilburg University, Department of Educational Psychology. Translated by H. Sun (2012) into simplified Chinese characters.

Vermunt, J. D. (1996). Metacognitive, cognitive and affective aspects of learning styles and strategies: A phenomenographic analysis. Higher Education, 31, 25-50.

Vermunt, J. D. (1998). The regulation of constructive learning processes. British Journal of Educational Psychology, 68(2), 149-171.

Vermunt, J. D. (2020). Surveys and retrospective self-reports to measure strategies and strategic processing. In D. L. Dinsmore, L. K. Fryer, \& M. M. Parkinson (Eds.), Handbook of strategies and strategic processing (pp. 259-274). Routledge.

Vermunt, J. D., \& Donche, V. (2017). A learning patterns perspective on student learning in higher education: State of the art and moving forward. Educational Psychology Review, 29(2), 269-299.

Vermunt, J. D., \& Vermetten, Y. J. (2004). Patterns in student learning: Relationships between learning strategies, conceptions of learning, and learning orientations. Educational Psychology Review, 16, 359-384.

Walker, J. D., Christopher, D., Brooks, C., \& Baepler, P. (2011). Pedagogy and space: Empirical research on new learning environments. EDUCAUSE Quarterly. Retrieved July, 2014, http:// www.educause.edu/erp/article/pedagogy-and-space-empirical-research-new-learningenvironments 
Watkins, D. A., \& Biggs, J. B. (Eds.). (1996). The Chinese learner: Cultural, psychological and contextual influences. Melbourne, Victoria: University of Hong Kong, Comparative Education Research Centre, \& Australian Council for Educational Research.

Wilson, K., \& Fowler, J. (2005). Assessing the impact of learning environments on students' approaches to learning: Comparing conventional and action learning designs. Assessment \& Evaluation in Higher Education, 30(1), 87-101.

Wiske, M. S. (Ed.). (1998). Teaching for understanding: Linking research with practice. San Francisco: Jossey-Bass.

Yu, J. (2019). Modelling learning space and student learning in higher education: An evidencebased exploration. In K. Fisher (Ed.), The translational design of universities: An evidencebased approach (pp. 205-219). Leiden \& Boston: Brill Sense. 